\title{
Pusat Pelayanan Informasi dan Pengaduan (Pindu) Kabupaten Pinrang Dalam Perspektif Best-Practice Manajemen Pengaduan
}

\author{
Andi Irna Amilia ${ }^{1 *}$, Amy Yayuk Sri Rahayu \\ ${ }^{1}$ Fakultas Ilmu Administrasi, Universitas Indonesia, Indonesia \\ ${ }^{2}$ Fakultas Ilmu Administrasi, Universitas Indonesia, Indonesia
}

\begin{abstract}
The Pinrang Regency Government tried to implement participatory governance in public services by optimizing the handling of public complaints. In doing so, The Government formed a Center for Information and Complaints Services (Pusat Pelayanan Informasi dan Pengaduan - PINDU) at the regency level so that the scope of complaint services was broader and more comprehensive. The Pinrang Regency Government also used the local budget (APBD) for creating an electronic complaint service application called "PINDU application." All these initiatives had led the Pinrang Regency Government as one of the pioneers in the implementation of integrated complaint services based on information and communication technology (electronic) in South Sulawesi and had also received any positive appreciations at both the national and regional levels. This study analyzed PINDU complaint management based on the best-practice concept of complaint management by Johnston and Mehra (2002). This study used a qualitative method. Data collection techniques were document analysis, observation, and interviews related to the topic. This study found that PINDU had optimally practiced one of the twelve best-practice characteristics of complaint management, namely the combination of centralized and decentralized complaint handling. Referring to this study's findings, PINDU can still improve its performance by optimizing eleven complaint management best-practices currently not optimally practiced
\end{abstract}

Keywords: complaint management; participatory governance; service complaint

\begin{abstract}
Abstrak
Pemerintah Kabupaten Pinrang berusaha mewujudkan tata kelola partisipatif dalam pelayanan publik melalui pengoptimalan penanganan pengaduan masyarakat. Salah satu upaya yang dilakukan adalah membangun Pusat Pelayanan Informasi dan Pengaduan (PINDU) pada tingkat Kabupaten sehingga lingkup pelayanan pengaduannya lebih luas dan menyeluruh. Pemerintah Kabupaten Pinrang juga berinisiatif menggunakan anggaran pendapatan dan belanja daerah (APBD) untuk membangun sebuah aplikasi pelayanan pengaduan elektronik yang diberi nama "aplikasi PINDU". Insiatif ini menjadikan Pemerintah Kabupaten Pinrang sebagai salah satu pelopor penyelenggaraan pelayanan pengaduan terintegrasi berbasis teknologi informasi dan komunikasi (elektronik) di Sulawesi Selatan dan mendapatkan penghargaan baik di tingkat nasional maupun daerah. Penelitian ini menganalisis manajemen pengaduan PINDU berdasarkan konsep best-practice manajemen pengaduan yang dikemukakan oleh Johnston dan Mehra (2002). Metode yang digunakan adalah kualitatif dengan teknik pengumpulan data berupa analisis dokumen, observasi dan wawancara. Penelitian ini menemukan bahwa PINDU telah mempraktikkan secara optimal satu dari dua belas karakteristik best-practice manajemen pengaduan yaitu adanya kombinasi penanganan pengaduan secara terpusat dan terdesentralisasi. Bila mengacu pada temuan penelitian ini, maka dapat disimpulkan bahwa PINDU masih dapat meningkatkan kinerjanya dengan mengoptimalkan penerapan sebelas best-practice manajemen pengaduan yang saat ini belum optimal dipraktikkan.
\end{abstract}

Kata Kunci: manajemen pengaduan; pengaduan layanan; tata kelola partisipatif

*irna19amilia@gmail.com

DOI: https://doi.org/10.26618/kjap.v6i3.4225 


\section{PENDAHULUAN}

Tata kelola partisipatif merupakan bentuk praktik demokrasi pelayanan publik dimana masyarakat dilibatkan dalam manajemen organisasi publik. Tata kelola partisipatif menjembatani masyarakat dan organisasi publik untuk menciptakan pelayanan publik yang efektif dan efesien melalui partisipasi langsung dalam pembuatan kebijakan, produksi barangbarang publik, pelibatan pada berbagai kegiatan serta pengawasan dan evaluasi program. Salah satu bentuk tata kelola partisipatif yang mendorong pemerintah untuk lebih efektif dan responsif terhadap kebutuhan masyarakat adalah penyampaian pengaduan, informasi dan saran dari masyarakat.

\section{Peraturan Presiden Nomor 76} Tahun 2013 menjelaskan bahwa pengaduan adalah penyampaian keluhan oleh pengadu kepada pengelola pengaduan pelayanan publik atas pelayanan pelaksana yang tidak sesuai dengan standar pelayanan atau pengabaian kewajiban dan/atau pelanggaran larangan oleh penyelenggara pelayanan publik. NSW Ombudsman (2017) mengartikan pengaduan sebagai ekspresi ketidakpuasan yang dibuat untuk atau tentang suatu organisasi terkait dengan produk, layanan, staf atau penanganan pengaduan dimana tanggapan dan penyelesaiannya secara implist atau eksplisit diharapkan atau diperlukan secara hukum. Tolba et al. (2015) menguraikan bahwa pengaduan adalah semua komunikasi tertulis, lisan atau elektronik yang digunakan pelanggan untuk menyatakan ketidaksenangan mereka mengenai kekurangan atau kegagalan suatu produk atau jasa. Pengaduan menjadi sebuah sumber informasi berharga tentang bagaimana dan dimana kesalahan organisasi dalam melakukan pelayanan.

Pelayanan pengaduan adalah kegiatan penyaluran pengaduan, pemrosesan respon atas pengaduan, umpan balik dan laporan penanganan pengaduan. Adapun elemen pelayanan pengaduan meliputi sumber atau asal pengaduan, isi pengaduan, unit penanganan pengaduan, respon pengaduan, umpan balik dan laporan penanganan pengaduan (Bappenas, 2010). Adapun NSW Ombudsman, (2015) mendefinisikan sistem penanganan pengaduan sebagai cara terorganisir untuk merespon, mencatat, melaporkan dan menggunakan pengaduan untuk meningkatkan layanannya kepada pelanggan. Termasuk prosedur bagi pelanggan untuk membuat keluhan dan pedoman bagi staf untuk menyelesaikan keluhan serta memberikan informasi yang dapat membantu manajer dan staf untuk mencegah terjadinya ketidakpuasan pelanggan di masa depan. 
Johnston, (2001) menguraikan bahwa adalah perbaikan manajemen pengaduan layanan yang melibatkan proses penerimaan, investigasi, penyelesaian dan pencegahan pengaduan serta pemulihan pelanggan. Manajemen pengaduan dapat memberikan dampak yang baik bagi organisasi.

Secara internal, manajemen pengaduan yang desainnya mudah digunakan oleh karyawan dan mampu memuaskan pelanggan, dapat membuat karyawan merasa memiliki kontrol yang lebih besar dan mengurangi tingkat stress mereka dalam menjalankan tugas dan fungsi di organisasi. Manajemen pengaduan juga dapat digunakan untuk mendukung keberlanjutan upaya peningkatan kinerja organisasi dengan memfokuskan perhatian manajemen pada masalah tertentu. Selain itu, organisasi yang memiliki budaya kerja terbuka terhadap pengaduan dan memiliki perencanaan strategis terkait pengaduan juga dapat mengalami peningkatan kinerja keuangan (Johnston, 2001).

Bagi eksternal organisasi, desain dan implementasi yang baik dari manajemen pengaduan dapat memiliki pengaruh yang besar terhadap tingkat kepuasan dan loyalitas pelanggan (Berry \& Parasuraman, 1991). Penanganan pengaduan yang efektif tidak hanya membantu perusahaan terhindar dari kehilangan pelanggan yang tidak puas kepada pesaing dan penyebaran gethok tular (word of mouth) negatif (Stauss, 2002) tetapi juga menguatkan niat pelanggan untuk membeli/menggunakan layanan kembali, meningkatkan kepercayaan dan komitmen pelanggan serta hubungan jangka panjang dengan pelanggan (Johnston \& Mehra, 2002). Hal senada diungkapkan oleh Filip (2013) bahwa dengan merancang sistem manajemen pengaduan yang terintegrasi, sebuah organisasi berkesempatan untuk mempelajari umpan balik pelanggan dan memanfaatkan informasi tersebut untuk mengurangi kelemahan organisasi, meningkatkan kinerja proses dan menghindarkan munculnya pengalaman negatif di masa datang sehingga akan membangun kembali kepuasan, loyalitas dan komitmen hubungan dari pelanggan kepada organisasi.

Para peneliti telah mengidentifikasikan sejumlah faktor yang menggambarkan 'manajemen pengaduan yang baik'. Diantara faktor-faktor tersebut terdapat sembilan faktor yang menjadi faktor utama yaitu respon cepat, perbaikan pelayanan, pemberian informasi, prosedur yang adil, pegawai yang sangat membantu, penjelasan tertulis, permohonan maaf, prosedur yang mudah dan kompensasi (Johnston, 2000).

Pada tahun 2002, Johnston dan Mehra mengungkapkan bahwa selain 'manajemen pengaduan yang baik (good practice 
complaint management)' terdapat pula 'manajemen pengaduan terbaik (bestpractice complaint management)' dengan dua belas karakteristik. Pertama, respon cepat dan manusiawi. Kedua, mendorong penyampaian pengaduan secara tepat. Ketiga, budaya tidak menyalahkan. Keempat, create-closure. Kelima, keterlibatan aktif pimpinan tertinggi. Keenam, memandang pengaduan sebagai isu strategis. Ketujuh, kombinasi antara penanganan pengaduan secara terpusat dan terdesentralisasi. Kedelapan, fokus pada komunikasi dan perbaikan. Kesembilan, sistem pengaduan internal. Kesepuluh, survei terkait masalah dan resolusi. Kesebelas, memfokuskan perhatian staf melalui pengetahuan tentang manfaat pengaduan. Keduabelas, memfokuskan perhatian manajemen senior melalui biaya dan penghematan dari pengaduan (Johnston \& Mehra, 2002).

Pada tahun 2014, Pemerintah Kabupaten (Pemkab) Pinrang, sebagai sebuah organisasi publik, membangun sarana pelayanan pengaduan masyarakat berbasis elektronik di tingkat Kabupaten. Sarana ini dibentuk melalui penerbitan Peraturan Bupati Pinrang Nomor 25 Tahun 2014 tentang Pusat Pelayanan Informasi dan Pengaduan (PINDU) Pemerintah Kabupaten Pinrang. PINDU merupakan lembaga non struktural yang berada di Sub Bagian Tata Laksana, Pelayanan Publik dan
Kinerja, Bagian Organisasi dan Tata Laksana, Sekretariat Daerah Kabupaten Pinrang. PINDU menjadi wujud dari upaya pemerintah kabupaten untuk mewujudkan tata kelola partisipatif dalam pelayanan publik dengan menyediakan sistem dan prosedur yang memungkinkan segala pengaduan, keluhan, protes ataupun informasi dari masyarakat Pinrang terkelola dengan baik dalam lingkup yang lebih luas dan menyeluruh. Akronim PINDU sengaja dipilih karena dalam bahasa BugisMakassar, kata PINDU berarti saudara sepupu. Pemilihan akronim ini diharapkan bisa mendorong masyarakat untuk berpartisipasi dalam tata kelola pemerintah dengan menyampaikan pengaduannya secara leluasa seperti berkeluh kesah dengan saudara sendiri.

Pemkab. Pinrang berupaya menyelenggarakan manajemen pengaduan terbaik melalui PINDU. Praktik-praktik yang dilakukan untuk mewujudkan hal itu antara lain menyusun visi, misi, sasaran, motto, alur kerja, standard operating procedure (SOP) dan standar pelayanan (SP). Seluruh pimpinan satuan kerja di lingkup Pemkab. Pinrang juga melakukan penandatangan pakta integritas sebagai bentuk komitmen mendukung kegiatan PINDU. Selain itu, Pemkab. Pinrang menyediakan anggaran khusus dan infrastruktur teknologi informasi seperi jaringan internet, jaringan telepon, 
perangkat komputer, telepon, website, email PINDU dan aplikasi khusus yang diberi nama "aplikasi PINDU". Aplikasi ini dirancang tidak hanya untuk memberikan manfaat bagi pemerintah berupa kemudahan dan pengintegrasian pelayanan pengaduan tetapi juga memudahkan masyarakat untuk menyampaikan dan memantau perkembangan penanganan pengaduan yang diajukannya.

Pemkab. Pinrang menjadi salah satu Pemerintah Daerah di Sulawesi Selatan yang mempelopori penyelenggaraan pelayanan pengaduan terintegrasi berbasis teknologi informasi dan komunikasi (elektronik) dengan membangun "aplikasi PINDU" menggunakan anggaran daerah/APBD. Selain itu, Pemkab. Pinrang juga berinisiatif untuk memberdayakan operator Pejabat Pengelola Informasi dan Dokumentasi (PPID) yang ada di setiap SKPD sebagai petugas PINDU SKPD. Terobosan pembangunan pelayanan pengaduan berbasis elektronik menjadikan pelayanan pengaduan di Kabupaten Pinrang yang semula parsial menjadi integratif antar seluruh unit kerja yang ada di lingkup Pemkab. Pinrang.

Berbagai upaya yang dipraktikkan Pemkab. Pinrang terkait manajemen pengaduan masyarakat ini mendapatkan apresiasi dari Pemerintah Pusat. Hal ini dibuktikan dengan ditetapkannya PINDU Pemkab. Pinrang sebagai salah satu dari top
99 Inovasi Pelayanan Publik 2015 oleh Kementerian Pendayagunaan Aparatur Negara dan Reformasi Birokrasi. Selain itu, PINDU juga mendapatkan penghargaan dari Fajar Institute Pro Otonomi (FIPO) sebagai pemenang "Daerah dengan Terobosan Inovatif Bidang Akuntabilitas Publik” (Sar, n.d.).

Apresiasi atas PINDU juga diberikan oleh anggota Ombudsman Republik Indonesia, Dadan S. Suharmawijaya, yang mengungkapkan bahwa salah satu di antara sedikit Pemerintah Daerah yang sejak awal berkomitmen atas pengelolaan pengaduan adalah Pemkab. Pinrang yang mendirikan PINDU. Apresiasi serupa juga diberikan oleh Kepala Perwakilan Ombudsman Republik Indonesia Provinsi Sulawesi Selatan, Subhan, yang menyatakan bahwa keberadaan PINDU menempatkan Pemkab.Pinrang sebagai Pemda yang paling sedikit dilaporkan ke Ombudsman terkait dugaan maladministrasi pelayanan publik. Lebih lanjut, Subhan menyatakan bahwa pada banyak kesempatan dalam mengisi acara di Kabupaten lain di Sulawesi Selatan, ia selalu menghimbau kepada Kepala Daerah untuk belajar tentang pengelolaan pengaduan di Kab.Pinrang dan tak perlu ke provinsi lain. Hal ini dikarenakan, di mata Perwakilan Ombudsman Provinsi Sulawesi Selatan, semua yang diterapkan di PINDU sudah sesuai dengan perintah Undang-Undang 
Nomor 25 Tahun 2009 tentang Pelayanan

Publik, terutama masalah pelayanan Pengaduan.

Berbagai praktik yang diterapkan oleh PINDU untuk mewujudkan manajemen pengaduan terbaik inilah yang menjadi fokus penelitian ini.

Hasil kajian pustaka yang dilakukan penulis menunjukkan bahwa penelitian dengan tema manajemen pengaduan yang diselenggarakan oleh instansi pemerintah di Indonesia, sebenarnya telah banyak dilakukan. Penelitian tersebut ada yang menggunakan konsep manajemen (Santoso \& Suwitri, 2018); konsep elemen penanganan pengaduan (Katon Mahendra \& Pribadi, 2014); konsep manajemen pengaduan yang diajukan Tjiptono (Mursalim, 2018; Satria \& Priyadi, 2020); maupun konsep electronict government sebagai alat analisis (Lestari et al., 2015). Dari penelitian-penelitian tersebut diketahui bahwa penanganan pengaduan di instansi Pemerintahan berjalan baik bila aspek input seperti sumber daya manusia, aturan, pedoman teknis, sarana prasarana, kerjasama dan kesadaran serta komitmen dari seluruh pegawai tersedia (Satria \& Priyadi, 2020; Katon Mahendra \& Pribadi, 2014). Selain itu pemanfaatan aplikasi sistem informasi seperti LAPOR! dapat membuat penanganan pengaduan pemerintah terintegarasi sehingga lebih cepat dan lebih tepat (Mursalim, 2018).
Adapun penyebab penanganan pengaduan tidak optimal antara lain penanganan yang tidak tepat waktu (Santoso \& Suwitri, 2018), rendahnya koordinasi dan persamaan persepsi tentang pelayanan dan pengelolaan pengaduan, kesiapan sumber daya manusia belum optimal, tidak adanya tim pengawas yang mengontrol tindak lanjut penanganan pengaduan, masih kurangnya umpan balik dari masyarakat, aplikasi sistem informasi pengaduan belum termanfaatkan secara maksimal, jaringan internet di instansi pemerintah sering mengalami gangguan, server sering bermasalah, masih adanya tata laksana penanganan pengaduan yang dilakukan secara manual seperti penyaluran pengaduan dari pegawai penerima pengaduan ke sub-sub bidang penanggungjawab penanganan pengaduan di masing-masing Instansi (Lestari et al., 2015).

Adapun penelitian ini bertujuan untuk menganalisis manajemen pengaduan PINDU dalam perspektif best-practice manajemen pengaduan yang dikemukakan oleh Johnston \& Mehra (2002). Sejauh kajian pustaka yang telah penulis lakukan, penggunaan konsep ini sebagai alat analisis manajemen pengaduan yang diselenggarakan oleh instansi Pemerintah di Indonesia masih belum ada. Dengan demikian, penelitian ini berbeda dari penelitian-penelitian sebelumnya dan 
diharapkan mampu mengisi kekosongan penelitian-penelitian tersebut.

\section{METODE PENELITIAN}

Penelitian ini dilakukan dengan pendekatan post-positivist yaitu pendekatan yang memiliki elemen reduksionis, logis, berdasarkan data empiris, berorientasi sebab akibat dan bergantung pada teori sebagai pedoman. Berdasarkan tujuan, penelitian ini termasuk penelitian deskriptif yaitu penelitian yang memberikan gambaran yang lebih detail mengenai manajemen pengaduan melalui PINDU. Berdasarkan dimensi waktu, penelitian ini merupakan penelitian cross-sectional dimana penelitian yang dilakukan dalam satu waktu tertentu dan tidak akan dilakukan penelitian lain di waktu berbeda untuk diperbandingkan.

Metode penelitian yang digunakan adalah kualitatif dengan teknik pengumpulan data berupa wawancara, analisis dokumen dan observasi. Wawancara dilakukan dengan informan yang ditentukan menggunakan teknik non probability dalam bentuk purposive (judgemental sampling) dimana informan dianggap ahli/memahami atau berasal dari orang-orang yang terlibat dalam manajemen PINDU Pemkab. Pinrang. Analisis dokumen dilakukan terhadap dokumen perencanaan, keuangan dan pelaporan Pemerintah Kabupaten Pinrang.
Lokus penelitian ini adalah Pusat Pelayanan Informasi dan Pengaduan (PINDU) Kabupaten Pinrang. Penelitian dilakukan pada bulan Maret 2019 hingga Agustus 2020. Ada empat tahapan yang dilakukan yaitu pengumpulan data, reduksi data, penyajian data, dan penarikan kesimpulan. Keabsahan data diuji menggunakan teknik triangulasi data dengan membandingkan data primer maupun sekunder yang dikumpulkan dengan temuan-temuan di lapangan.

\section{HASIL DAN PEMBAHASAN}

Adapun analisis praktik manajemen pengaduan di PINDU Pemkab. Pinrang ditinjau dari 12 (dua belas) best-practice manajemen pengaduan yang dikemukakan Johnston \& Mehra (2002) adalah sebagai berikut:

\section{Respon Cepat yang Manusiawi}

Menurut Johnston \& Mehra (2002), tanggapan atas pengaduan wajib diberikan secepat mungkin. Jawaban atau solusi atas pengaduan juga harus diberikan secepatnya serta dilengkapi dengan penjelasan tentang penyebab dan rincian tindakan yang diambil. Sebisa mungkin pengadu juga dihubungi melalui telpon agar memberikan kesempatan bagi organisasi untuk menghadirkan sisi kemanusiaan kepada pengadu. Menunjukkan bahwa penanganan 
pengaduan bukan hanya rutinitas organisasi melainkan bentuk kepedulian organisasi kepada pengguna layanan.

Hasil olah data pengaduan masyarakat Pinrang melalui PINDU pada tahun 2018-2019 (lihat tabel 1) menunjukkan bahwa respon cepat sebagai salah satu karakteristik best-practice manajemen pengaduan belum dipraktikkan secara optimal di PINDU. Hal ini dibuktikan dengan adanya pengaduan yang waktu penyelesaiannya tidak sesuai dengan

standar waktu yang ditetapkan dalam Peraturan Bupati Pinrang Nomor 25 Tahun 2014, Pasal 26 angka (1) huruf (h), huruf (i). Dalam Peraturan tersebut dijelaskan bahwa respon awal atas pengaduan masyarakat paling lama 2 kali 24 jam sedangkan jawaban atas pengaduan adalah 2 kali 24 jam untuk pengaduan yang melibatkan satu SKPD atau 6 kali 24 jam untuk pengaduan yang melibatkan lebih dari satu SKPD. Ketidaksesuaian tersebut tergambarkan pada tabel 1berikut:

Tabel 1.

Kesesuian waktu pelayanan informasi dan pengaduan masyarakat terhadap Peraturan Bupati Pinrang Nomor 25 Tahun 2014

\begin{tabular}{|c|c|}
\hline Uraian & Jumlah Pengaduan \\
\hline Pelayanan yang sesuai standar waktu & 49 \\
\hline Pelayanan yang tidak sesuai standar waktu & 46 \\
\hline $\mathrm{n} / \mathrm{a}$ & 62 \\
\hline Total & 157 \\
\hline
\end{tabular}

Sumber : Laporan Tahunan Pusat Pelayanan Informasi dan Pengaduan (PINDU) Kabupaten Pinrang Tahun 2018 -2019.

Dalam pengamatan peneliti, hingga saat ini, tak jarang petugas PINDU masih harus turun langsung ke satuan kerja perangkat daerah (SKPD) untuk mengkoordinasikan tindak lanjut pengaduan karena telah mendekati batas maksimal waktu respon SKPD sebagaimana diatur dalam Perbup 25/2014. Kondisi ini tentunya membutuhkan waktu penanganan yang lebih lama dan tentunya menghabiskan sejumlah biaya. Padahal keputusan membangun PINDU sebagai layanan pengaduan berbasis elektronik diambil karena diharapkan bisa mengefesienkan pelayanan dari segi waktu dan biaya.

Adapun penyebab keterlambatan penanganan pengaduan melalui PINDU beragam. Salah satunya bahwa saat ini aplikasi PINDU hanya bisa memfasillitasi penyaluran pengaduan secara online dari pengawai PINDU yang berada di tingkat 
pusat organisasi (Kantor Bupati Pinrang) ke petugas PINDU di masing-masing SKPD. Sementara penyaluran pengaduan dari petugas PINDU SKPD ke atasan atau ke bagian/bidang yang memiliki kewenangan dan tanggungjawab secara teknis menyelesaikan isu pengaduan masih dilakukan secara manual. Proses penyaluran manual ini tentunya memperlambat proses penanganan pengaduan di tingkat SKPD, terlebih bila atasan/pejabat berwenang sedang melaksanakan tugas luar kantor/tugas keluar kota atau sedang memprioritaskan kegiatan kantor lainnya. Keterlambatan respon pengaduan juga terkadang disebabkan oleh jaringan internet PINDU dan/atau SKPD yang sering mengalami gangguan (mati atau tidak stabil) sehingga mengakibatkan aplikasi PINDU tidak berjalan secara optimal.

Namun demikian, pegawai PINDU menegaskan bahwa dengan segala keterbatasan yang dihadapi, mereka senantiasa berusaha untuk sebisa mungkin menghubungi pengadu secara langsung melalui telepon ketika jawaban atas pengaduan telah ada atau penanganan pengaduan menemui kendala dalam pelaksanaannya. Langkah tersebut diharapkan dapat menunjukkan tingkat kepedulian Pemerintah terhadap pengaduan masyarakat meski menemui beberapa kendala yang menyebabkan terjadinya keterlambatan penanganan pengaduan masyarakat.

\section{Mendorong Penyampaian Pengaduan secara Tepat}

Dalam konsep Johnston \& Mehra (2002) diuraikan bahwa sebuah organisasi yang menyelenggarakan layanan jasa wajib mendorong pengguna layanannya untuk mau menyampaikan keluhan/aduannya. Organisasi juga wajib menyediakan berbagai metode/sistem yang tepat dan mudah digunakan oleh pengguna untuk melakukan hal tersebut. 
Gambar 1. Alur Kerja PINDU

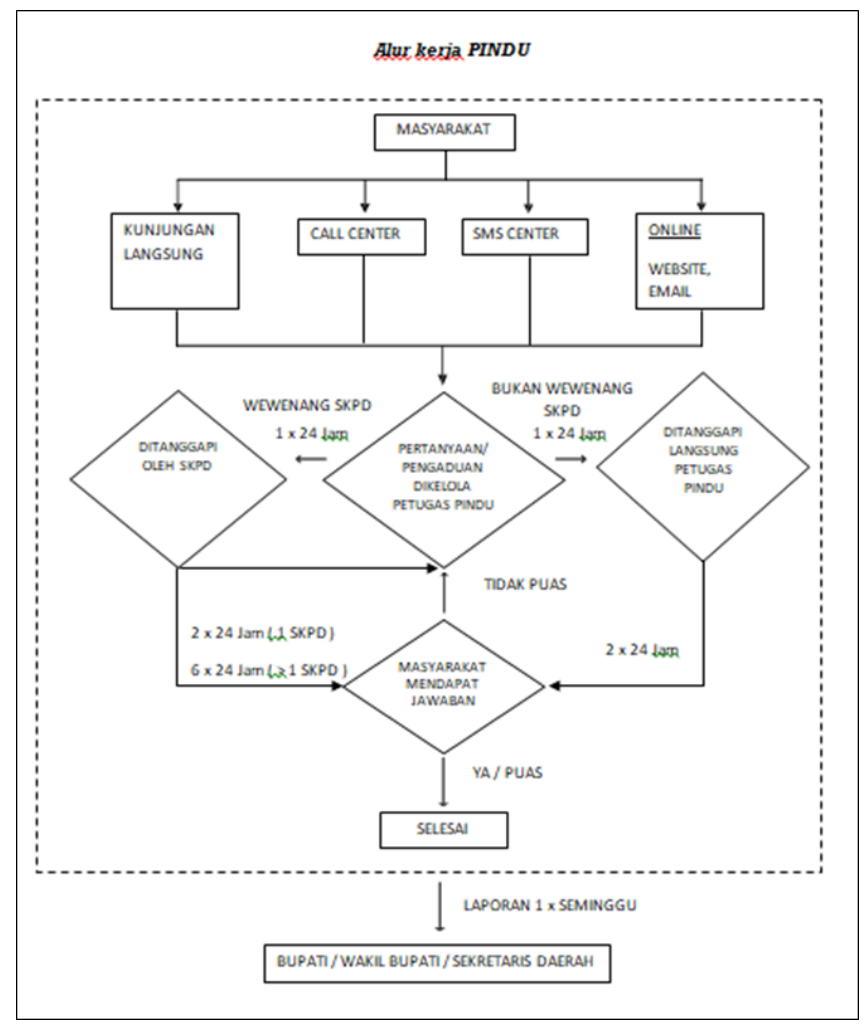

\section{Sumber: Peraturan Bupati Pinrang Nomor 25 Tahun 2014}

Bila meninjau alur kerja PINDU (lihat gambar 1) diketahui bahwa Pemkab.Pinrang telah berusaha mendorong masyarakat untuk mau menyampaikan keluhan/aduannya melalui PINDU dengan menyediakan empat saluran pengaduan. Pertama, kunjungan langsung ke kantor PINDU di kompleks Kantor Bupati Pinrang, Jl. Bintang Nomor 1 Kabupaten Pinrang. Kedua telepon/call center dengan nomor (0421) 922-759 atau 0811-4167599. Ketiga, Short Message Service (SMS) ke nomor 081-391-471-171 dengan format \#no.ktp\#nama\#alamat\#isi pengaduan. Keempat, daring/Internet melalui website https://pindu.pinrangkab.go.id, email dengan alamat: pindu@pinrangkab.go.id. Mulai tahun 2018 PINDU juga memanfaatkan aplikasi whatsapp dengan nomor 0811-416-7599 dan menyediakan akun facebook PINDU sebagai saluran pengaduan yang dapat digunakan oleh masyarakat.

Hasil analisis dokumen perencanaan dan pelaporan terkait kegiatan PINDU juga menunjukkan bahwa setiap tahunnya Pemkab. Pinrang melakukan sosialisasi agar masyarakat mengetahui keberadaan PINDU. Sosialisasi ini dilakukan dalam bentuk pertemuan, pamflet, spanduk, baliho dan iklan di stasiun radio (Dokumen Pelaksanaan Anggaran (DPA) Sekretariat 
Daerah Kabupaten Pinrang, 2014; 2015; 2016; 2017; 2018; 2019). Namun demikian, berdasarkan hasil survei mengenai persepsi masyarakat terhadap kualitas layanan PINDU diketahui bahwa 15 dari 103 masyarakat yang menggunakan layanan PINDU pada rentang tahun 2018-2019 merasa bahwa intensitas sosialisasi PINDU masih kurang sehingga perlu ditingkatkan. Lebih lanjut, mereka berpesan agar PINDU disosialisasikan secara aktif di perdesaan karena menurut mereka, saat ini keberadaan PINDU lebih banyak diketahui oleh masyarakat yang berada di ibu kota Kabupaten (Amilia, 2020)

Selain secara kuantitas, kualitas sosialisasi juga perlu ditingkatkan. Misalnya, sosialisasi tidak hanya ditujukan kepada tokoh masyarakat di setiap kecamatan tapi juga menyasar kelompokkelompok potensial penerima pelayanan publik seperti pelajar-pelajar di sekolah, mahasiswa di perguruan tinggi, ibu rumah tangga di posyandu, pemuka agama dan masyarakat umum di tempat ibadah dll.

\section{Budaya tidak Menyalahkan}

Munculnya inisiatif dari Bupati Pinrang selaku pimpinan tertinggi organisasi untuk membangun PINDU sebagai pusat pelayanan pengaduan masyarakat dengan anggaran daerah mengindikasikan bahwa Pemkab. Pinrang membuka diri dan menerima pengaduan sebagai konsekuensi dari kesalahan yang tentunya bisa terjadi saat melayani masyarakat dengan beragam urusan. Melalui PINDU, Pemkab. Pinrang berusaha menjadikan pengaduan sebagai sebuah kelaziman dalam pemerintahan. Hal ini sejalan dengan yang diungkapkan oleh Johnston \& Mehra (2002) bahwa organisasi wajib menerima kesalahanan dan menjadikan pengaduan sebagai kenormalan positif dari kehidupan organisasi.

Usaha ini tentunya tidak mudah. Menurut pegawai PINDU, pada awal pendiriannya, keberadaan PINDU tidak diterima secara langsung oleh SKPD. Hal ini dikarenakan dalam pandangan mereka saat itu, pengaduan masyarakat ke PINDU berpotensi untuk membangun citra buruk tentang kinerja mereka kepada pimpinan. Keberadaan PINDU juga dinilai telah mengambil alih kewenangan pemerintah wilayah (camat, lurah, kepala desa, kepala lingkungan, kepala dusun) dalam menangani masalah masyarakat. Menurut mereka, PINDU seharusnya tidak menerima pengaduan dari masyarakat yang belum ditangani secara berjenjang mulai dari tingkat lingkungan/dusun, kelurahan/desa dan kecamatan. Namun demikian, dalam perkembangannya, penilaian tersebut mulai memudar. Saat ini, SKPD khususnya pemerintah wilayah sudah menyadari bahwa PINDU hanyalah 
salah satu saluran atau pintu alternatif bagi masyarakat untuk menyampaikan aduannya. Pengaduan yang masuk melalui PINDU akan tetap diselesaikan oleh SKPD teknis secara berjenjang. Prinsip tak ada pintu yang salah untuk orang mengadu (no wrong door policy) perlahan mulai dipahami oleh SKPD.

\section{Create-Closure}

Johnston \& Mehra (2002) menguraikan bahwa sebuah organisasi wajib memastikan pengguna puas dengan hasil yang diperolah dari pengaduannya (eksternal closure). Selain itu, organisasi juga harus belajar dari pengaduan tersebut dan bila memungkinkan, melakukan perubahan pada proses bisnisnya agar permasalahan yang sama tidak terjadi berulang. Internal closure juga harus dilakukan melalui mekanisme saran yang melibatkan manager senior untuk memastikan bahwa perubahan yang tepat telah dilakukan pada proses dan sistem.

Eksternal create-closure pengaduan melalui PINDU telah diatur dalam Peraturan Bupati Pinrang Nomor 25 Tahun 2014, pasal 26 ayat (1) huruf j, dimana pengadu diberi kesempatan untuk merespon hasil penanganan pengaduannya. Bila pengadu tidak puas terhadap hasil tersebut maka petugas PINDU akan menerima kembali permohonan ketidakpuasan pengadu sebagai pengaduan baru dan memprosesnya sebagaimana pengaduan baru diproses. Bila pengadu telah puas atau tidak menanggapi hasil penanganan selama 3 kali 24 jam setelah dijawab maka penanganan pengaduan akan dinyatakan selesai. Meski telah berpedoman pada peraturan tersebut, proses create-closure yang dilakukan tersebut ternyata tidak menjamin bahwa masyarakat telah puas dengan penanganan pengaduan oleh PINDU. Dari survei kualitas pelayanan PINDU ditemukan bahwa ternyata ada masyarakat yang tidak puas dengan hasil penanganan pengaduannya namun memilih tidak menggunakan haknya untuk menanggapi hasil penanganan pengaduan karena beragam pertimbangan (Amilia, 2020). Berdasarkan hal tersebut, maka diperlukan penyempurnaan mekanisme eksternal create-closure untuk memastikan bahwa masyarakat puas dengan hasil yang diperoleh dari penanganan pengaduannya melalui PINDU. Misalnya petugas PINDU secara pro-aktif menelpon pengadu yang tidak menggunakan haknya di hari terakhir batas waktu tanggapan untuk memastikan bahwa pengadu telah menerima hasil/solusi yang diberikan oleh Pemerintah terkait masalah yang diadukan.

Adapun internal create-closure pengaduan melalui PINDU belum optimal dilakukan. Analisa terhadap Laporan Tahunan Pusat Pelayanan Informasi dan 
Pengaduan Pemkab. Pinrang, 2018; 2019) menunjukkan bahwa masih terdapat pengaduan dengan isu/permasalahan berulang. Kondisi ini mengindikasikan bahwa organisasi di lingkup Pemkab.Pinrang belum menjadikan data pengaduan sebagai rujukan dalam menyusun perencanaan kerja atau rujukan dalam melakukan perubahan pada proses kerjanya sehingga permasalahan yang sama kembali diadukan oleh masyarakat. Adapun permasalahan berulang yang dimaksud, diantaranya adalah penumpukan sampah dan lampu jalan. Johnston (2000) mengungkapkan bahwa manajemen pengaduan seharusnya tidak hanya berupaya untuk memuaskan pengadu tetapi juga menjadi bagian dari pembelajaran berkelanjutan dan siklus perbaikan dengan menggunakan masukan dari masyarakat dan pegawai tentang kegagalan yang terjadi, potensi kegagalan dan masalah yang mungkin terjadi.

\section{Memandang Pengaduan sebagai Isu Strategis}

Hasil tinjauan terhadap dokumen perencanaan dan pelaporan Pemkab. Pinrang menunjukkan bahwa pimpinan tertinggi Pemkab.Pinrang (Bupati Pinrang) Periode 2014-2019 memberikan dukungan tinggi kepada PINDU. Hal ini terlihat dengan dimasukkannya penanganan pengaduan melalui PINDU sebagai salah satu indikator kinerja pada Rencana Pembangunan Jangka Menengah Daerah (RPJMD) Kabupaten Pinrang 2014-2019 (2014). Disamping itu, Pemkab.Pinrang juga mengalokasikan anggaran khusus untuk operasional PINDU dengan membuka rekening tersendiri bagi PINDU pada dokumen perencanaan dan pengganggaran daerah pada tahun anggaran 2014 dengan nomenklatur "Kegiatan Peningkatan Pelayanan Publik" (Dokumen Pelaksanaan Anggaran (DPA) Sekretariat Daerah Kabupaten Pinrang Tahun 2014, 2014). Praktik ini sejalan dengan bestpractice manajemen pengaduan Johnston \& Mehra (2002) dimana organisasi memandang pengaduan tidak hanya sebagai masukan penting terhadap peningkatan operasional organisasi tetapi juga menjadi masukan penting pada perencanaan strategis untuk kesuksesan jangka panjang organisasi.

Namun demikian, bila meninjau turunan dokumen Rencana Pembangunan Jangka Menengah Daerah (RPJMD) Kabupaten Pinrang 2014-2019 tersebut ke tingkat satuan kerja perangkat daerah (SKPD) dan Laporan Kinerja Instansi Pemerintah (LKJIP) Tahun 2019 ("Laporan Kinerja Instansi Pemerintah,” 2019), maka terlihat bahwa penanganan pengaduan melalui PINDU belum menjadi prioritas. Hal ini diindikasikan dengan belum 
dijadikannya masalah terkait pengaduan pada tahun-tahun sebelumnya sebagai indikator kinerja utama SKPD dan rujukan dalam menyusun rencana kerja (renja) SKPD. Dengan begitu, tidak mengherankan bila pengaduan dengan permasalahan yang sama masih saja ditemukan (berulang) setiap tahunnya. Kondisi ini juga diindikasikan oleh belum adanya anggaran khusus yang dialokasikan SKPD lainnya, selain oleh Sekretariat Daerah yang menjadi instansi induk PINDU, untuk penanganan pengaduan. Beberapa SKPD menganggarkan penanganan pengaduan menyatu pada anggaran kegiatan, khususnya anggaran perjalanan dinas dalam daerah. Namun ada pula beberapa SKPD yang tidak mengalokasikan anggaran pengaduan sama sekali.

Selanjutnya, bila meninjau dokumen Rencana Pembangunan Jangka Menengah Daerah (RPJMD) Kabupaten Pinrang 2019-2024, (2019) diketahui bahwa Pemerintah Periode 2019-2024 tidak memasukkan penanganan pengaduan melalui PINDU sebagai salah satu indikator kinerja. Hal ini menunjukkan bahwa meski meneruskan kebijakan Pemerintah sebelumnya (periode 2014-2019) terkait penyelenggaraan pelayanan pengaduan melalui PINDU, namun Pemerintah periode 2019-2024 tidak memasukkan penyelenggaraan pelayanan pengaduan melalui PINDU tersebut sebagai salah satu isu strategis Pemerintahan. Kondisi ini tentunya sangat disayangkan, mengingat hasil penelitian Johnston \& Mehra (2002) mengungkapkan bahwa penyelenggaraan pengaduan perlu dimasukkan dalam sistem perencanaan strategis. Mereka menemukan bahwa organisasi-organisasi sukses selalu memandang pengaduan tidak hanya sebagai kontributor kunci dalam upaya perbaikan operasional organisasi tetapi juga menjadi kontributor kunci untuk mencapai keberhasilan jangka panjang organisasi (Johnston \& Mehra, 2002).

\section{Keterlibatan Aktif Pimpinan Tertinggi}

Bupati Pinrang periode 2019-2024, Irwan Hamid selaku pimpinan tertinggi pemerintahan daerah telah memberikan sumbangsing dalam perbaikan penanganan pengaduan masyarakat di Kabupaten Pinrang dengan melanjutkan program Bupati periode 2014-2019, Aslam Patonangi, yang memprakarsai terbentuknya pusat pelayanan pengaduan dan informasi yang mewujud sebagai PINDU dan menginisiasi talk show on air bertajuk "Halo Bumi Lasinrang" dalam bingkai "masyarakat bicara, pemerintah mendengar" untuk menjaring pengaduan dan informasi masyarakat.

Namun demikian, inisiasi yang didukung dengan pengalokasian anggaran, infrastruktur dan sumber daya manusia 
tersebut belum disertai keterlibatan aktif pimpinan daerah (Bupati dan Wakil Bupati Pinrang), periode 2014-2019 maupun periode 2019-2024, dalam aspek penanganan pengaduan di garis depan. Hal ini disebabkan pimpinan daerah telah menyerahkan dan mempercayakan penangangan pengaduan pada tim koordinasi yang meliputi pengelola PINDU dan para pimpinan SKPD. Selain itu, pimpinan daerah juga mengandalkan laporan mingguan dari PINDU untuk mengontrol perkembangan penanganan pengaduan. Umumnya, pimpinan daerah baru terlibat aktif bila pengaduan tersebut menjadi isu yang mengemuka dan tidak terselesaikan di tingkat tim koordinasi penanganan pengaduan. Padahal bila bercermin pada penanganan pengaduan di sektor swasta yang menjadi rujukan penerapan tata kelola new public service di sektor publik, keterlibatan pimpinan tertinggi dalam berbagai aspek manajemen pengaduan di garis depan akan memberikan beberapa keuntungan diantaranya memungkinkan pimpinan tertinggi untuk mempelajari informasi yang banyak dan rinci tentang produk dan pelayanan organisasi sehingga aspek kunci yang menyebabkan pengguna layanan merasa tidak puas dapat diketahui dan perubahanperubahan dalam organisasi dapat dilakukan untuk memenuhi harapan pengguna layanan tersebut (Zeithaml, Parasuraman, \& Berry, 1990).

Pendapat ini sejalan dengan temuan (Johnston \& Mehra, 2002) bahwa dukungan dan keterlibatan pimpinan tertinggi dalam berbagai aspek manajemen pengaduan di garis depan akan menunjukkan tingkat keseriusan mereka memandang pengaduan. Selain itu juga menunjukkan tingkat kepedulian mereka yang nyata tidak hanya bagi pengadu tapi juga staf. Keterlibatan aktif juga memberikan kesempatan untuk mempelajari sebanyak mungkin mengenai penyebab mengapa organisasi gagal memuaskan pengadu serta memberikan dorongan untuk membuat perubahan yang akan menciptakan perbedaan dalam pelayanan pengaduan.

\section{Kombinasi antara Penanganan Pengaduan secara Terpusat dan Terdesentralisasi}

Alur kerja PINDU pada gambar 1 menunjukkan bahwa manajemen penanganan pengaduan melalui PINDU telah mengkombinasikan penanganan pengaduan secara terpusat dan terdesentralisasi. Bila masyarakat mengajukan pengaduan melalui salah satu saluran yang disediakan, maka pegawai PINDU yang berada di pusat organisasi (kantor Bupati Pinrang) akan menelaah isi pengaduan untuk selanjutnya 
didistribusikan ke SKPD yang memiliki tugas, fungsi dan kewenangan terkait pengaduan tersebut. SKPD yang menjadi unit desentralisasi menindaklanjuti distribusi pengaduan dengan mengambil langkah-langkah penyelesaian pengaduan diantaranya mericek isi pengaduan, mengumpulkan informasi lanjutan, mengadakan pertemuan, memberikan solusi, melaporkan perkembangan atau penyelesaian pengaduan ke PINDU sesuai jangka waktu yang telah diatur dalam Peraturan Bupati Pinrang Nomor 25 Tahun 2014. Laporan penanganan pengaduan dari berbagai SKPD selanjutnya direkap oleh pegawai PINDU selaku pengelola pengaduan di tingkat Pusat (Kabupaten) untuk dilaporkan ke pimpinan daerah (Bupati dan Wakil Bupati Pinrang) setiap hari Jumat. Setiap tahunnya, laporan tersebut juga dibuat dalam bentuk laporan tahunan.

Kondisi ini sejalan dengan temuan Johnston \& Mehra (2002) bahwa manajemen pengaduan yang baik membutuhkan pendekatan terpusat dan terdesentralisasi meski alokasi tugas dapat bervariasi. Unit desentralisasi harus digunakan untuk mengumpulkan informasi, berinteraksi langsung dengan pengadu dan mengurus masalah yang menjadi kewenangannya sedangkan departemen/tim/individu di tingkat pusat organisasi bertanggungjawab menganalisis trend pengaduan sebagai rujukan pengambilan kebijakan dan mencari perbaikan terkait pengaduan tersebut.

\section{Fokus pada Komunikasi dan Perbaikan}

Komunikasi penanganan pengaduan melalui PINDU belum berjalan optimal. Laporan penanganan pengaduan yang disusun secara berkala (mingguan, bulanan dan tahunan) oleh Pegawai PINDU belum disebarkan secara luas ke seluruh SKPD lingkup pemerintah kabupaten Pinrang. Laporan ini secara rutin dan terbatas disampaikan hanya kepada Sekretaris Daerah, Bupati dan Wakil Bupati. Padahal dalam laporan tahunan diuraikan trend pengaduan setiap SKPD meliputi jumlah aduan, objek permasalahan dan persentasenya terhadap total pengaduan serta bukti penanganan pengaduan (Laporan Tahunan Pusat Pelayanan Informasi dan Pengaduan Pemkab. Pinrang, 2018; 2019).

Meski laporan pengaduan yang dibuat oleh pegawai PINDU memberikan gambaran mengenai trend pengaduan yang masuk. Namun laporan tersebut hanya dijadikan alat kontrol perkembangan penanganan pengaduan masyarakat oleh pimpinan daerah, belum dimanfaatkan sebagai rujukan dalam penyusunan kebijakan, perencanaan strategis organisasi, perbaikan program/kegiatan atau 
pengawasan kinerja terkait trend pengaduan tersebut. Padahal bila merujuk pada penelitian Johnston \& Mehra (2002) laporan mengenai masalah pengaduan dan poin-poin pembelajaran perlu disebarkan secara luas ke seluruh lingkup organisasi. Hal ini dilakukan agar data pengaduan dapat digunakan untuk mendorong pemahaman yang sama tentang masalah pengaduan dan analisa trend pengaduan dapat dijadikan rujukan untuk kebijakan dan mencari perbaikan terkait pengaduan. Hal ini sejalan dengan pernyataan (Zeithaml et al., 1990) bahwa informasi yang digali dari data pengaduan seharusnya dikumpulkan dan diberikan kepada manajemen untuk dijadikan masukan ketika merencanakan dan menyediakan/memasarkan sebuah produk atau jasa.

\section{Sistem Pengaduan Internal}

Sistem pengaduan internal belum tersedia secara formal di lingkup Pemerintah Kabupaten Pinrang. Petugas PINDU dan pengelola pengaduan di tingkat SKPD hanya menyampaikan gagasan atau keluhan terkait penanganan pengaduan melalui tatap muka dengan pimpinan atau mengemukakan pada rapat staf. Belum ada aturan yang menguraikan mekanisme sistem pengaduan internal PINDU. Padahal temuan Johnston \& Mehra, (2002) mengungkapkan bahwa salah satu bestpractice manajemen pengaduan adalah staf digunakan sebagai sumber utama gagasan. Saran, masalah dan pengaduan mereka harus dicatat, dilacak dan ditangani secara serius dan sistematis sebagaimana pengaduan dari pelanggan.

\section{Survei Terkait Masalah dan Resolusi}

Sejak berdiri di tahun 2014, pengelola PINDU telah melakukan survei kepuasan masyarakat terhadap pelayanan PINDU. Survei ini belum optimal memberikan gambaran mengenai tingkat kepuasan pengadu terhadap pelayanan PINDU dikarenakan: pertama, kuisoner yang digunakan untuk mengevaluasi pelayanan pengaduan pada tahun 2014 hingga 2019 masih mengacu pada Peraturan Menteri pendayagunaan aparatur negara dan reformasi birokrasi Nomor 14 Tahun 2017 tentang pedoman penyusunan survei kepuasan masyarakat untuk penyelenggara pelayanan publik sehingga hanya menyajikan kepuasan masyarakat secara umum terhadap pelayanan publik, tidak fokus mencari informasi terkait masalah dan resolusi pelayanan pengaduan; Kedua, kuisoner hanya diberikan kepada pengadu yang berkunjung langsung ke PINDU dan ketiga, laporan hasil survei tidak khusus menggambarkan pelayanan PINDU semata tetapi secara umum menggambarkan 
pelayanan sekretariat daerah selaku organisasi induk. Padahal dalam konsep best-practice manajemen pengaduan Johnston dan Mehra (2002), survei yang dimaksudkan adalah survei yang tidak boleh jauh dari upaya untuk mencari informasi terkait masalah dan resolusi manajemen pengaduan.

\section{Memfokuskan Perhatian Staf melalui Pengetahuan tentang Manfaat Pengaduan}

Hasil tinjauan terhadap dokumen perencanaan dan pelaporan menunjukkan bahwa Pemerintah Kabupaten Pinrang belum optimal melakukan sosialisasi kepada staf tentang manfaat pengaduan bagi organisasi (Dokumen Pelaksanaan Anggaran (DPA) Sekretariat Daerah Kabupaten Pinrang, 2014; 2015; 2016; 2017; 2018; 2019) dan "Laporan Kinerja Instansi Pemerintah,” 2019 ). Sosialisasi yang pernah dilakukan masih terbatas kepada staf yang bekerja di bagian perencanaan dan staf yang menangani pengaduan. Hal ini menjadikan pengetahuan staf terkait manfaat pengaduan belum merata utamanya pada staf yang tidak berkaitan dengan tugas perencanaan dan pengaduan. Sosialisasi tersebut juga hanya bersifat insidental, tidak dilakukan secara rutin. Kondisi ini secara tidak langsung berdampak pada tingkat respon staf terhadap pengaduan. Pengaduan masyarakat tidak menjadi prioritas staf dalam melaksanakan tugas, terlebih disaat tugas rutin lainnya mendesak untuk diselesaikan. Padahal pengetahuan tentang manfaat pengaduan bagi organisasi ini diharapkan memberikan motivasi kepada staf untuk menangani pengaduan secara positif (Johnston \& Mehra, 2002).

\section{Memfokuskan Perhatian Manajemen} Senior melalui Informasi tentang Biaya dan Penghematan yang Dapat Dilakukan dari Penanganan Pengaduan

Bila menelaah laporan penanganan pengaduan PINDU maka diketahui bahwa laporan tersebut belum menyediakan informasi tentang biaya dan manfaat pengaduan bagi SKPD (Laporan Tahunan Pusat Pelayanan Informasi dan Pengaduan Pemkab. Pinrang, 2018; 2019). Petugas PINDU di tingkat Kabupaten yang bertugas menganalisa trend pengaduan belum menghitung kerugian yang ditimbulkan oleh permasalahan yang diadukan bagi setiap SKPD (diantaranya biaya staf, kompensasi, waktu) sehingga belum diketahui besaran anggaran yang dapat dihemat bila masalah tersebut dapat diselesaikan dan/atau tidak terjadi secara berulang.

Hal ini terjadi antara lain dikarenakan pimpinan belum memberikan instruksi 
untuk melakukan penghitungan biaya dan manfaat pengaduan, disamping pegawai PINDU belum memiliki pengetahuan tentang cara menganalisa biaya dan manfaat pengaduan tersebut. Padahal bila merujuk pada Johnston \& Mehra (2002) motivasi untuk para pimpinan organisasi harusnya disediakan melalui informasi keuangan tentang biaya dan manfaat penanganan pengaduan. Organisasi menghitung kerugian yang ditimbulkan oleh isu/permasalahan yang diadukan (diantaranya biaya staf, kompensasi, waktu) sehingga diketahui besaran anggaran yang dapat dihemat bila masalah tersebut dapat diselesaikan dan/atau tidak terjadi secara berulang. Informasi ini ditunjukkan kepada para pimpinan dan staf dengan harapan dapat memfokuskan pikiran mereka pada realitas praktis yang terjadi bila mereka tidak melakukan hal yang benar di kesempatan pertama.

\section{KESIMPULAN}

Pusat pelayanan informasi dan pengaduan (PINDU) menjadi wujud dari upaya Pemkab. Pinrang dalam mengoptimalkan pelayanan pengaduan bagi masyarakatnya. Aturan, sumber daya manusia, anggaran, sarana dan prasarana telah disediakan untuk mendukung kinerja
PINDU. Penghargaan dan apresiasi dari berbagai pihak pun diterima Pemkab. Pinrang. Bila ditinjau dari perspektif bestpractice manajemen pengaduan yang diajukan oleh Johnston \& Mehra ( 2002) maka PINDU Pemkab. Pinrang telah mempraktikkan secara optimal satu dari dua belas karakteristik best-practice manajemen pengaduan yaitu adanya kombinasi penanganan pengaduan secara terpusat dan terdesentralisasi. Meski demikian, masih terdapat delapan karakteristik yang belum optimal dipraktikkan meliputi respon cepat yang manusiawi, mendorong penyampaian pengaduan secara tepat, budaya tidak menyalahkan, create-closure, memandang pengaduan sebagai isu strategis, keterlibatan aktif pimpinan tertinggi, fokus pada komunikasi dan perbaikan serta memfokuskan perhatian staf melalui pengetahuan tentang manfaat pengaduan. Adapun karakteristik best-practice manajemen pengaduan yang belum diterapkan sama sekali ada tiga yaitu adanya survei terkait masalah dan resolusi, sistem pengaduan internal dan memfokuskan perhatian para pimpinan organisasi melalui analisa biaya dan penghematan dari penanganan pengaduan.

Bila mengacu pada temuan penelitian ini, maka dapat disimpulkan bahwa PINDU masih dapat meningkatkan kinerjanya dengan mengoptimalkan penerapan sebelas 
best-practice manajemen pengaduan yang saat ini belum optimal dipraktikkan. Misalnya, dengan menjadikan laporan penanganan pengaduan PINDU sebagai salah satu rujukan dalam merencanakan program dan kegiatan Pemerintah setiap tahunnya baik ditingkat Kabupaten maupun SKPD.

\section{UCAPAN TERIMA KASIH}

Penulis menghaturkan banyak terima kasih kepada Pemerintah Kabupaten Pinrang, khususnya Bagian Organisasi dan Tata Laksana, Sekretariat Daerah Kabupaten Pinrang yang berkenan menyediakan data dan informasi terkait tulisan ini.

\section{DAFTAR PUSTAKA}

Amilia, A. I. (2020). Hasil Survei Kualitas Pelayanan Pusat Pelayanan Informasi dan Pengaduan (PINDU) Tahun 2020 Diukur dengan Pendekatan Hierarchical Model of Perceived Service Quality.

Bappenas. (2010). Manajemen Pengaduan Masyarakat dalam Pelayanan Publik. Laporan Kajian.

Berry, L. L., \& Parasuraman, A. (1991). Marketing Services: Competing Through Quality. New York: Free Press.

Dokumen Pelaksanaan Anggaran (DPA) Sekretariat Daerah Kabupaten Pinrang Tahun 2014. (2014). Kabupaten Pinrang.

Dokumen Pelaksanaan Anggaran (DPA) Sekretariat Daerah Kabupaten Pinrang Tahun 2015. (2015). Kabupaten Pinrang.
Dokumen Pelaksanaan Anggaran (DPA) Sekretariat Daerah Kabupaten Pinrang Tahun 2016. (2016). Kabupaten Pinrang.

Dokumen Pelaksanaan Anggaran (DPA) Sekretariat Daerah Kabupaten Pinrang Tahun 2017. (2017). Kabupaten Pinrang.

Dokumen Pelaksanaan Anggaran (DPA) Sekretariat Daerah Kabupaten Pinrang Tahun 2018. (2018). Kabupaten Pinrang.

Dokumen Pelaksanaan Anggaran (DPA) Sekretariat Daerah Kabupaten Pinrang Tahun 2019. (2019). Kabupaten Pinrang.

Filip, A. (2013). Complaint Management: A Customer Satisfaction Learning Process. Procedia - Social and Behavioral Sciences. https://doi.org/10.1016/j.sbspro.2013. 09.188

Johnston, R. (2000). Complaint Management. OR Insight, 13(4), 9-13. https://doi.org/10.1057/ori.2000.17

Johnston, R. (2001). Linking complaint management to profit. International Journal of Service Industry Management.

https://doi.org/10.1108/09564230110 382772

Johnston, R., \& Mehra, S. (2002). Bestpractice complaint management. Academy of Management Executive. https://doi.org/10.5465/AME.2002.89 51342

Katon Mahendra, G., \& Pribadi, U. (2014). Efektivitas Pelaksanaan Pelayanan Pengaduan Masyarakat Berbasis EGovernment. Journal of Governance and Public Policy. https://doi.org/10.18196/jgpp.2014.00 03

Laporan Kinerja Instansi Pemerintah. (2019). Retrieved from https://pinrangkab.go.id/laporankinerja-instansi-pemerintah/

Laporan Tahunan Pusat Pelayanan Informasi dan Pengaduan Pemkab. Pinrang Tahun 2018. (2018). 
Laporan Tahunan Pusat Pelayanan Informasi dan Pengaduan Pemkab. Pinrang Tahun 2019. (2019).

Lestari, Y., Luh, N., Fil, S., Wismayanti, D., \& Wiwin, K. (2015). ... Pelayanan Publik Berbasis E-Government (Studi Kasus Pengelolaan Pengaduan Rakyat Online Denpasar Pada Dinas Komunikasi dan Informatika Kota Denpasar .... Citizen Charter.

Mursalim, S. W. (2018). Analisis Manajemen Pengaduan Sistem Layanan Sistem Aspirasi Pengaduan Online Rakyat (LAPOR) di Kota Bandung. Jurnal Ilmu Administrasi: Media Pengembangan Ilmu Dan Praktek Administrasi. https://doi.org/10.31113/jia.v15i1.128

NSW Ombudsman. (2015). Complaint Management Framework. In NSW Ombudsman.

https://doi.org/10.4135/97814833463 66.n22

NSW Ombudsman. (2017). Effective Complaint Handling Guidelines, 3rd Edition. Retrieved from http://www.ombo.nsw.gov.au/_data/ assets/pdf_file/0018/42228/Effectivecomplaint-handling-guidelines-Thirdedition.pdf

Peraturan Bupati Pinrang Nomor 25 Tahun 2014. (n.d.). Pinrang: Pemerintah Kabupaten Pinrang.

Peraturan Presiden Nomor 76 Tahun 2013. (2013). Peraturan Presiden Nomor 76 Tahun 2013. Jakarta, Indonesia: Pemerintah Indonesia.

Rencana Pembangunan Jangka Menengah Daerah (RPJMD) Kabupaten Pinrang 2014-2019. (2014). Kabupaten Pinrang.

Rencana Pembangunan Jangka Menengah Daerah (RPJMD) Kabupaten Pinrang 2019-2024. (2019). Kabupaten Pinrang.

Santoso, C., \& Suwitri, S. (2018). Manajemen Pengaduan Masyarakat di Pusat Pengelolaan Pengaduan Masyarakat (P3M) Kota Semarang. Journal of Public Policy and
Management Review.

Sar. (n.d.). Ombudsman RI Pantau Pelayanan Publik Pemkab Pinrang. Sahabat News Online. Retrieved from https://sahabatnewsonline.wordpress.c om/2016/09/30/sahabat-newsombudsman-ri-pantau-pelayananpublik-pemkab-pinrang/

Satria, J. V., \& Priyadi, B. P. (2020). Sistem Manajemen Pengaduan Masyarakat melalui Lapor! Kemendagri. Journal Of Public Policy And Management Review, 9(2), 285-299. Retrieved from https://ejournal3.undip.ac.id/index.ph p/jppmr/article/view/27360/23881

Stauss, B. (2002). The dimensions of complaint satisfaction: process and outcome complaint satisfaction versus cold fact and warm act complaint satisfaction. Managing Service Quality: An International Journal. https://doi.org/10.1108/09604520210 429240

Tolba, A., Seoudi, I., Meshreki, H., \& Shimy, M. (2015). Effect of Justice in Complaint Handling on Customer Loyalty: Evidence from Egypt. Global Journal of Business Research.

Zeithaml, V. A., Parasuraman, A., \& Berry, L. L. (1990). Delivering Quality Service: Balancing Customer Perceptions and Expectations. In Free Press. New York. 